\title{
The Model of Organization and Personnel Management Autonomy at Vietnam National University Hanoi - Situation and Challenges
}

\author{
Nguyen Kieu Oanh ${ }^{1}$, Pham Thi Thanh Hai ${ }^{2}$, Tran Thi Hoai ${ }^{3}$ \\ ${ }^{I}$ VNU Organization Personnel Department, 144 Xuan Thuy, Cau Giay, Hanoi, Vietnam \\ ${ }^{2}$ VNU University of Education, 144 Xuan Thuy, Cau Giay, Hanoi, Vietnam \\ ${ }^{3}$ VNU Institute of Education Quality Assurance, 144 Xuan Thuy, Cau Giay, Hanoi, Vietnam
}

Received 19 April 2018

Revised 02 May 2018; Accepted 14 May 2018

\begin{abstract}
An institution of higher autonomy is the key to the reforms to diversify and effectively mobilize mutual resources in higher education at Vietnam National University, Hanoi (VNU). At present, the Vietnamese Government has issued some guidelines to grant more autonomous power to higher education institutions. Vietnam National University, Hanoi is moving toward an autonomous system to maximize the utilization of its resources to train high quality human resources for the nation. The autonomy of organization and personnel management is the prerequisite for a university to implement its autonomy mechanism and to be socially responsible for its training, scientific research, and technology transfer activities. During such empowerment, both objective and subjective factors should be seriously considered to develop effective implementing methods that fit each university's socioeconomic situation and particular characteristics.
\end{abstract}

Keywords: Higher education, autonomy at VNU; autonomy model, personnel management at Vietnam National University, Hanoi.

\section{Introduction}

University autonomy is viewed as the trend for development. Autonomy gives universities the motivation to renovate for more efficiency, diversified training activities and better competitiveness among higher education institutions. There fore, a globally common trend is the gradual shift from a state control

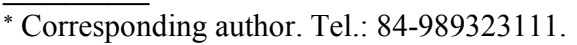

Email: oanhnk@vnu.edu.vn

https://doi.org/10.25073/2588-1159/vnuer.4132
}

model to a more autonomous model, from state control to state supervision.

Overview reports on the trend of worldwide university governance by the World Bank 2008 [1] recognize four models of university governance with the different degrees of autonomy ranging from complete state control as in Malaysia, to semi-autonomous models Autonomous) as in France and New Zealand, semi-independent - Independent in Singapore; to semi-autonomous models in the UK, Australia. However, in the state controlled model, higher education institutions still enjoy a 
certain level of autonomy for financial and practical reasons. The state cannot control all activities of the institution; In addition, even in the independent model, there are still implicit assumptions about the rights of the state to hold some strategic control and the right to demand high accountability in institutions.

Canada (AUCC) listed a list of university autonomy options for staff selection and appointment; Selection, recruitment and discipline of students; Establish and control training programs; Promulgation of organizational regulations for the implementation of academic activities; Program development and direct auxiliary resources; Certificate of completion and diploma awarding. This concept has too many aspects that each person in a different perspective has a different emphasis [2].

Over the years, autonomy situation in higher education in Vietnam has improved largely. The whole universities system, once run as one single big university under the tight control of the government via the Ministry of Education and Training, was gradually given autonomous power as found in the government's legal documents. The universities operate under an autonomy mechanism, have full legal person status and deciding power and are responsible for their own training and research activities as well as organizational, personnel and financial issues.

The granting of autonomous power to VNU's members and subordinate units aims to foster more effective operations and fulfill social demand. And the institution of higher autonomy is the key factor in the reforms to diversify and efficiently utilize the mutual resources of Vietnam National University, Hanoi.

\section{Vietnam Policy in granting autonomous power to universities}

2.1. Policy in granting autonomous power to universities
Recently, the Vietnamese government has paid special attention to the issue of university autonomy and has endeavored to create a legal framework for the autonomous power of higher education institutions, to ensure the supervising and monitoring role of the community and to enhance the role of various communities and public organizations, especially professional associations, in supervising the quality of undergraduate education. However, such autonomous power has yet to take effect due to the inconsistency and incompleteness of the government's policies and regulations. Higher education institutions still long for more autonomy, especially in financial management, organization, personnel, enrollment, equipping and facility, etc [3].

On February $14^{\text {th }}, 2015$, the Government issued Decree No. 16/2015/NĐ-CP governing the autonomy mechanism of public institutions [4]. The Decree has timely met the demand for renovation and development of public administrative activities in the socialist-oriented market economy. The Decree governs the operation and financial management of public administrative institutions towards granting them more autonomy and self-responsibility power and encouraging capable institutions to have higher autonomy.

\subsection{Autonomy Model at Vietnam National University, Hanoi}

2.2.1. VNU has three administrative management levels, including:

1) VNU, handles annual goals and plans by the Government, has legal status and possesses an official seal incorporating the national emblem. The president and vice presidents of VNU are appointed and discharged by the Prime Minister.

2) Member universities, research institutes; schools; training, science, and technology research centers, service units for training, science and technology researching under VNU as VNU's subordinate units. They have independent legal status, officialseals, and separate bank accounts. 
3) Departments and research divisions and equivalents under member universities, research institutes and service units.

VNU operates under a highly autonomous \& self-responsible mechanism. It works directly with ministries and ministerial and governmental agencies as well as provincial people's committees on issues relevant to its operation and development. VNU's member universities and research institutes are training and/or research units with high autonomy and have full legal person status as provided by the Law on Education, Law on Higher Education and Law on Science and Technology.

On November $17^{\text {th }}$ 2013, the Government issued Decree No 186/2013/NĐ-CP on the National Universities [5]. According to Article 2 of this Decree, the National University is a post-secondary education institution that consists of member universities and research institutes in various fields and is organized as a two-tier institution to train undergraduates and post-graduates (master, and doctoral students). It is a high-quality, multidisciplinary, multisectoral training, ascientific and technological research center with focuses on science, high technology, and some key socioeconomic areas.

\subsubsection{Personnel management at VNU}

Since its establishment in 1993, VNU's working staff has increased rapidly in both quantities and quality. By the end of 2016, VNU had more than 4,000 staffs, including 1,941 lecturers $(37 \%$ of whom are professors and associate professors, $58 \%$ doctors and doctors of science), 87 People's Teachers and nearly 200 Meritorious Teachers. These are top figures among the universities nationwide [6].

To manage the staffs and particularly the lecturers, VNU has a system of personnelrelated management documents to administer and guide its staff members and lecturer recruitment, employment, remuneration, training, upgrading and evaluating activities as well as in salary and social insurance policies.

VNU empowers its member universities and research institutes to have autonomy in personnel management and in the formulation and implementation of their operation plans, only the outcome of which is reported to VNU for approval. VNU only manages staffs of senior lecturer and equivalent scale while junior lecturers and equivalents downwards are managed by the rectors/directors of the respective member university/institutes. Regarding subordinate units, VNU approves their reports of the personal scheme before such schemes are implemented by the units. [7]

2.2.3. Organization and personal autonomy at $\mathrm{VNU}$

Member universities and research institutes develop their own organizational development strategies and reportto the VNU President for comments and reviews before such strategies are issued by the respective rector/directors. Basing on the strategy, the rector/director issues regulations on the organization and operation or function and responsibilities of the units within such university/institute and reports toVNU President for information. VNUmember universities/institutes are to report to the VNU director their plans to implement their organizational and personneltasks such as formation, dissolution of subordinate units, recruitment and employment, training policy, appointment, evaluation, reward and penalties of staffs, etc. Only then the universities/ institutes can carry out the relevant procedures. Upon the proposals of the faculties, training, science, and technology research centers and service units (hereinafter referred to as units) VNU approves the units' strategic development plans and issues the regulations on the unit's organization and operation. Basing on these, the units develop plans to implement their organizational and personel tasks (formation, dissolution of subordinate units, recruitment and employment, training policy, appointment, evaluation, reward and penalties of staffs, etc.) and report to VNU President for approval before implementation. Upon completion of the relevant procedures, the units report to VNU President of the outcome for afinal decision.

The Hanoi National University model is considered to be highly autonomous in the 
Vietnamese higher education system. With the orientation of granting autonomy to higher education institutions, especially forcus on the organizational and personel autonomy at VNU, this research was conducted to understand the implementation of organizational and personel autonomy at VNU and knowledge of the lecturers' managers on the power and criteria to appoint rectors/directors of VNU member universities, recruitment and appointment of staffs, Authority to Issue Unit Regulations and the salary [8].

\section{Research result and discussion}

\subsection{Survey method}

The author surveyed the situation of organizational and personel autonomy through a questionnaire sent to 256 staffs currently working at 18 member and subordinate units of VNU. SPSS software is used for analyzing this data.

To understand more about the awareness and expectations of VNU staffs in the implementation of organizational and personel autonomy, we surveyed 256 staffs currently working at VNU's member universities, research institutes and faculties, of which 106 are males (equaling 41.41\%) and 150 are female (58.59\%). (See Figure No.1)

\section{Gender Structure}

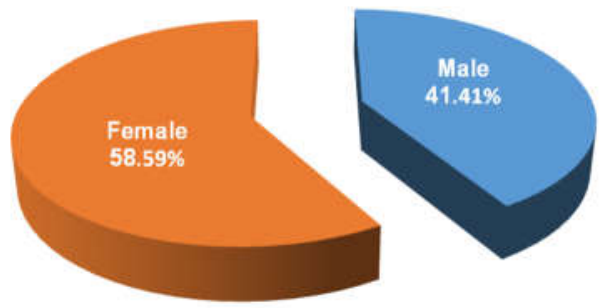

Figure 1. Gender Structure of the Survey Sample.

Working positions of the 256 surveyed staffsare as follows: 74 managerial staffs (28.91\%); 75 departmental and divisional staffs (29.30\%); 87 lecturers (33.98\%); 4 technicians $(1.56 \%) ; 16$ researchers $(6.25 \%)$. (See Figure No.2).

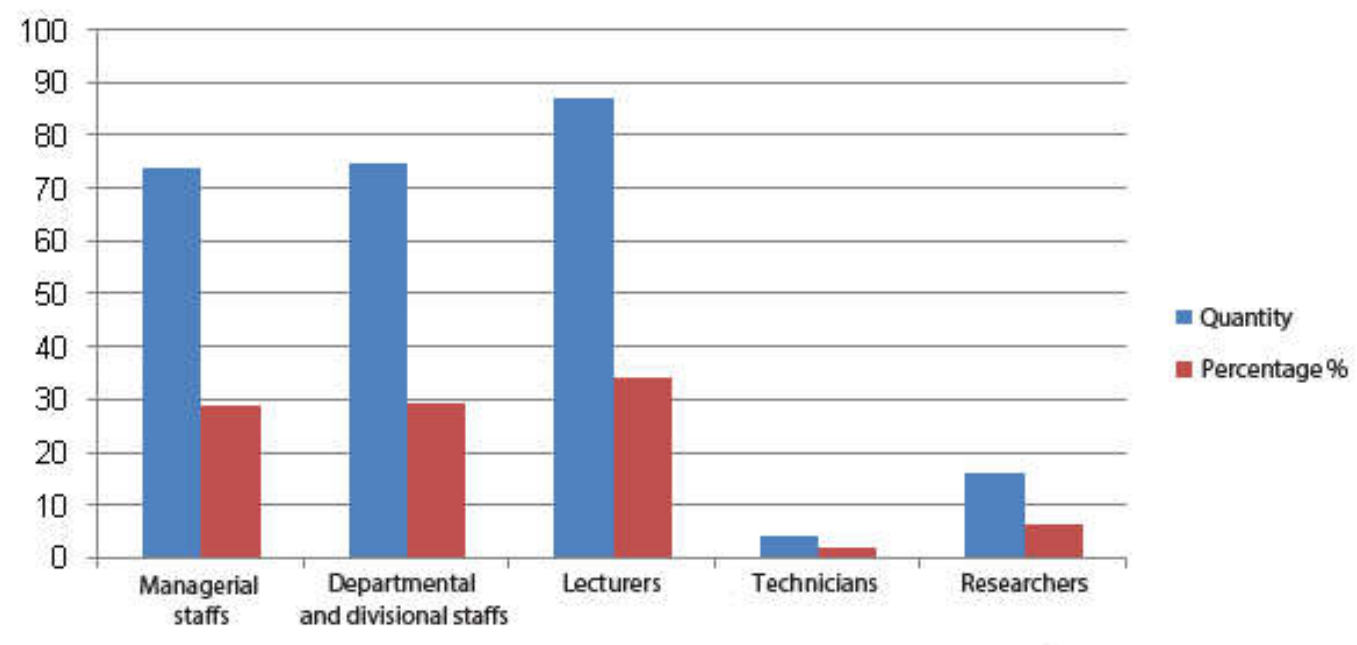

Figure 2. Working Positions of the Surveyed Staffs.

Educational qualifications of the surveyed staffs are as follows: 116 doctors (equaling 45.31\%); 105 masters (41.02\%); 35 bachelors
$(12.11 \%), 4$ of whom are medical doctors (1.56\%). (See Figure 3). 
The study was conducted with the questionnaire on the university autonomy. The university autonomy in organizational structure were analyzed: (i) Power and Criteria to Appoint Rectors /Directors; (ii) Staff Recruitment and Appointment Criteria; (iii) Authority to Issue Unit Regulations; (iv) Level of Agreement with Granting Unit Autonomy in Staff Salary Payment.

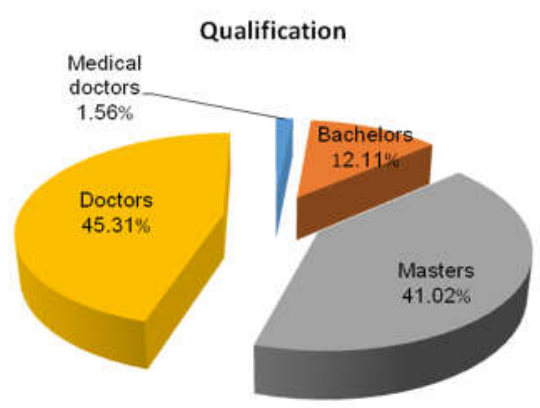

Figure 3. Qualification of the Surveyed Staffs.

\subsection{Research result}

a) Regarding the power and criteria to appoint rectors/directors of VNU member universities /research institutes, 178 out of 256 surveyed staffs (equaling 69.53\%) replied that the power and criteria to selectrectors/directors of VNU member universities/research institutes should be proposed by the respective universities/research institutes to VNU President, who considers such proposals and signs the appointing decision; 70 staffs $(27.34 \%)$ replied that such power and criteria should be completely decided internally within the unit and 08 staffs (accounting for 3.13\%) opted to leave the power to VNU President. The above figures show that the majority of the surveyed staffs do not see the necessity of VNU granting complete autonomy to its subordinate units in the formulation of criteria to select sectors/directors of such units. (See Table 1).

A further question was asked to clarify the reasons why the majority of the surveyed staff opted for VNU not giving full autonomy to its members in deciding the criteria to appoint rectors/directors. $49 \%$ of the answers agreed with objectivity reason while $24 \%$ disagreed and $27 \%$ were uncertain. (See Figure No. 4).

So, despite the desire to be given more autonomy for their university/institute, the staffs still want a higher management level (namely VNU) to appoint their rectors/directors. This is to ensure objectivity and the appointment of those who are influential, have good connections within VNU and are capable of cooperating in training and scientific research with advanced universities in the region and in the world.

b) Regarding recruitment and appointment of staffs in VNU's subordinate and member units, 125 out of 256 surveyed staffs (equaling $48.83 \%$ ) agreed that all positions should be decided within the respective unit while 131 staffs $(51.17 \%)$ said that certain positions should be decided by the VNU. However, $100 \%$ of the surveyed staffs agreed that VNU should not decide all positions in its subordinate and member units. (See Table 2).

Table 1. Power and Criteria to Appoint Rectors /Directors

\begin{tabular}{lcc}
\hline $\begin{array}{l}\text { Power and criteria to appoint } \\
\text { rector/director should be }\end{array}$ & Quantity & Percentage (\%) \\
\hline Decided within the unit & 70 & 27.34 \\
Proposed by the unit and decided by VNU & 178 & 69.53 \\
Decided by VNU & 8 & 3.13 \\
\hline Total & 256 & 100.00 \\
\hline
\end{tabular}




\section{Power and Criteria for Appointing Rectors/Directors \\ Fully disagree \\ Disagree \\ Uncertain \\ Agree \\ Fully agree}

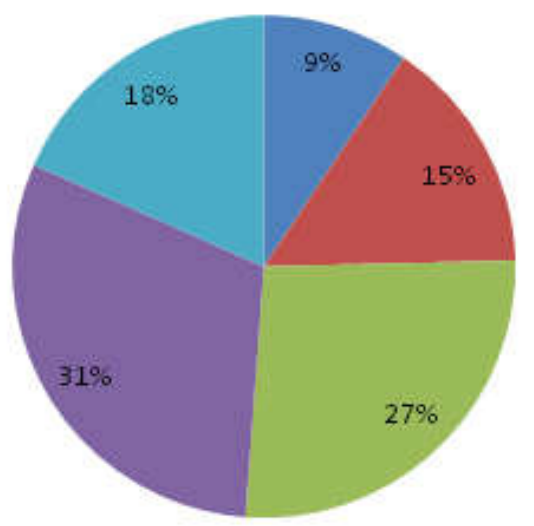

Figure 4. Power and Criteria to Appoint Rectors/Directors.

Table 2. Recruitment and Appointment of Staffs

\begin{tabular}{lll}
\hline $\begin{array}{l}\text { Recruitment and appointment of staffs } \\
\text { in the units should }\end{array}$ & Quantity & Percentage (\%) \\
\hline Be decided by the units for all positions & 125 & 48.83 \\
Be decided by VNU for some positions & 131 & 51.17 \\
Be decided by VNU for all positions & 0 & 0.00 \\
\hline Total & 256 & 100.00 \\
\hline
\end{tabular}

As the result of the above survey, most staffs expect the university to decide on their own positions and appoint them, except for some positions with high academic qualifications (such as professors, associate professors or over-aged scientists who are still in good health for teaching and researching).

149 out of 256 surveyed staffs (equaling $58.2 \%$ ) agreed that the recruiting and appointing criteria should be decided by the units. (See Table 3).

Table 3. Staff Recruitment and Appointment Criteria

\begin{tabular}{lcc}
\hline $\begin{array}{l}\text { Recruitment and appointment criteria } \\
\text { in the units should }\end{array}$ & Quantity & Percentage (\%) \\
\hline Be decided by the units & 149 & 58.20 \\
Be decided by VNU & 58 & 22.66 \\
Be decided by the government & 49 & 19.14 \\
\hline Total & 256 & 100.00 \\
\hline
\end{tabular}


On the level of agreement with the statement on the pros and cons of unit autonomy in staff recruitment and appointment, the results are as follows:

$84 \%$ of the surveyed staffs agreed that recruitment and appointment of unit staff should be decided within the respective units for maximum staff employment efficiency, only $6 \%$ disagreed with unit autonomy in this respect (10\% were uncertain). (See Figure 5). c) Regarding the authority to issue unit regulations, 138 staffs (equaling 53.91\%) agreed that the units may have full power in issuing its internal regulations; 115 staffs $(44.92 \%)$ thought that the units should propose the regulations to $\mathrm{VNU}$ for its decision and 03 staffs $(1.17 \%)$ believed that VNU should have full power in issuing the regulations for its members and subordinate units. (See Table No.4).
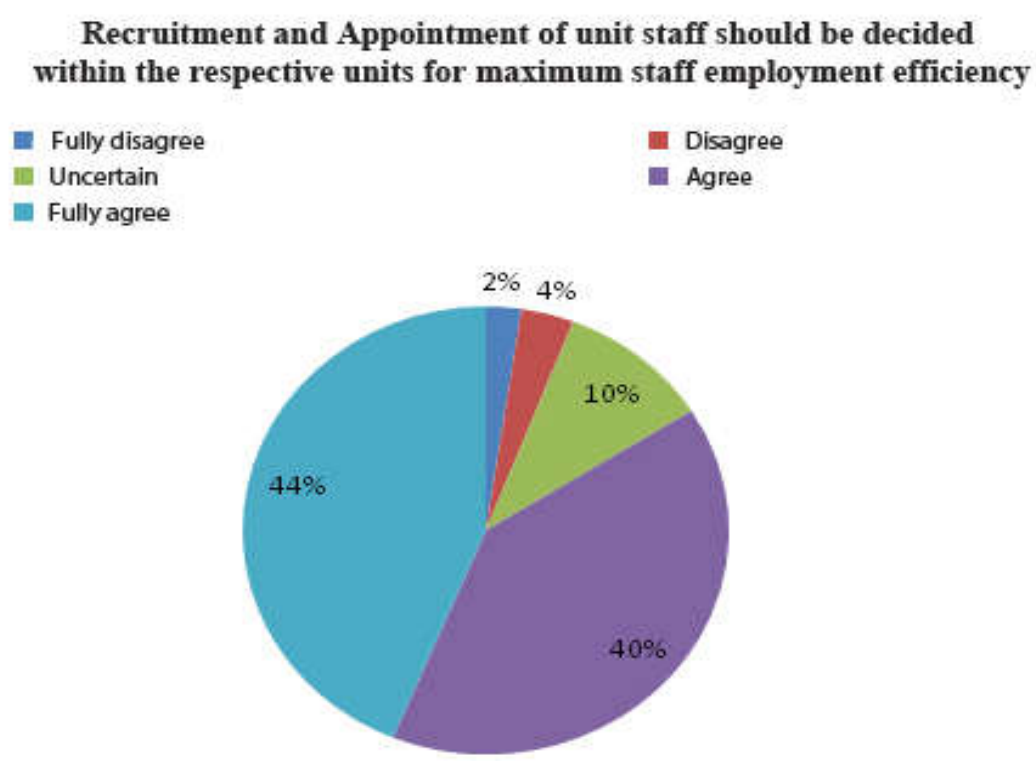

Figure 5. Agreement with the Statement on the Pros and Cons of Unit Autonomy in Staff Recruitment and Appointment.

Table 4. Authority to Issue Unit Regulations

\begin{tabular}{lcc}
\hline Unit regulations should & Quantity & Percentage (\%) \\
\hline Be issued by the units without limitation & 138 & 53.91 \\
Be proposed by the units and decided by VNU & 115 & 44.92 \\
Be wholly issued by VNU & 3 & 1.17 \\
\hline Total & 256 & 100.00 \\
\hline
\end{tabular}

Nearly $50 \%$ of the surveyed staffs still want VNU to issue managerial documents. We believe this is because the existing system of governmental legal documents governing graduate education is numerous and difficult to apply. As such, the member universities/institutes still need to rely on VNU to establish a favorable and open legal framework for autonomy in developing their own organization.

d) Staff salary

On question about the agreement of the surveyed staffs to the statement that VNU units should be authorized to decide salary for their 
staffs to ensure equality, 214 out of 256 (equaling 84\%) agreed and completely agreed to authorize full autonomy to the units in staff salary, only 16 (accounting for 6\%) disagreed or completely disagreed (while $10 \%$ were uncertain) (see Figure 6). The result shows that the payment of salary to the staff must be in proportion with task and responsibility allocation and must be done equally and fairly among the staffs. Therefore, the head of the units should be the one who decides salary payment basing on each staff's performance, capability and products.

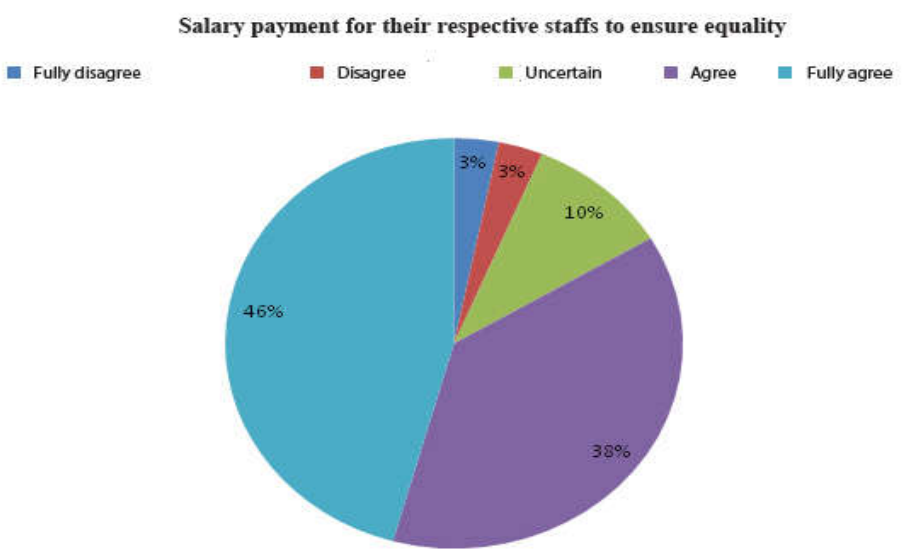

Figure 6. Level of Agreement with Granting Unit Autonomy in Staff Salary Payment.

\subsection{Discussion}

\subsubsection{Remarks}

a) Tasks should be reviewed and classified, considering the level of impacts on the units/individuals to make the final dicision on granting autonomy to the respective unit or staff. As for tasks wherein autonomy is agreed upon by most of the surveyed staffs, unit autonomy should be considered (following planned itinerary). Regarding tasks that are not yet agreed by the majority, increasing understanding of the policy to grant unit autonomy is needed, resources support to the units to carry out their tasks should be continued and evaluation of the units' autonomy capacity should be done annually to develop an appropriate itinerary for empowering unit autonomy.

b) When considering granting autonomous power to VNU's members, priority should be given to setting up a system of managerial documents that is sufficient, open and favorable to the scientists who are teaching and researching there. A focus of such a system should be on the documents on organization and personnel management.

c) VNU has substantially empowered member universities/institutes and subordinate units in the recruitment, employment, and appointment of staffs, except some leading positions. However, for flexibility in employing the existing staffs, a set of criteria to evaluate the level of task completion per job title should be developed. Basing on that, the leaders of the unit can evaluate and arrange jobs suitable to each staff. This is the starting point for effective employment of the human resource at VNU's member universities/institutes and subordinate units when these are granted with autonomous power.

d) When granted with autonomous power, VNU's member universities/institutes and subordinate units should develop a mechanism for paying salary and extra earnings basing on the evaluation of the staff's capability, tasks performance, and final products. 
e) As some surveyed staffs are not fully aware of the issue (i.e. the percentage of staffs being uncertain with the questions), more propagation is required to provide sufficient information and to improve VNU units' staff awareness of the importance and inevitability of unit autonomy in the current socio-economic context.

3.3.2. Some challenges to VNU unit autonomy and the reasons thereof

a. Challenges to organizational autonomy

- VNU's members and subordinate units still lack pro-activeness in realizing adjustment, restructuring and organizational structure development. Some units have not issued all the required internal regulations and stillrely onVNU'soverall regulations...

- The units' self-responsibility is not satisfactory and the cooperation in task implementation is sometimes inefficient, which leads to certain shortcomings and limitations during the implementation of unit autonomy.

b. Challenges to personel autonomy

- The recruitment and termination of employment contract must comply with the Labor Code and the Law on Public Administrative Staff, which inherently limits the role of university directors (e.g. Over-aged working, appointment of non-public staff as managers, etc. are not allowed);

- Rectors/Unit directors are not allowed to develop their own units' salary scale but to comply with the common scale issued by the Ministry of Internal Affairs. The current mechanism of salary payment is still on thethree-year term (i.e. pay rise every 3 years), which is yet based on employees' capability and productivity.

- Rectors are not allowed to approve scientists' eligibleness to confer the titles of Professors and Associate Professors. Neither are they entitled to dismiss these titles when the scientists fail to accomplish their tasks.

- Policies for the staffs are difficult to implement due to the incomprehensive policies of the government and the delays of guiding documents.

\subsubsection{Reasons}

- Objective reasons: State budget is increasingly restrictive and public capital mobilization is limited while VNU units' facilities and infrastructure in Hanoi inner city area do not meet their operational requirements and the scope of training and scientific research development as construction progress of VNU's new premises in Hoa Lacis slow.

- Subjective reasons: The training institutions want more freedom as a result of autonomy, while they still require the safeness of state budget funding. Meanwhile, VNU's units are different in terms of condition and capacity to realize autonomy rights. As such, the university needs to review the actual situation and categorizes its units to decide the appropriate level of autonomous power to be granted to the units. Training units with highly popular programs such as University of Economics and Business, University of Engineering and Technology, International School, School of Business may find it much easier to realize autonomy than such units as University of Science and University of Social Sciences and Humanities, which require more state budget funding for training and doing basic science research. Moreover, the deployment of autonomy rights of the units has not been effective; they focus mostly on autonomy of training and tuition fee, while little attention is paid to strategic and long-term investment to bring about significant and sustainable resources in the future, such as adjustment and restructure of the organization, development of high-quality human resources or research and development of new scientific and technological areas and training programs.

3.4. Recommendations on organization and personnel management model to promote autonomy in Vietnam National University, Hanoi

Basing on the review of the survey result and the analysis of some major challenges to theorganization and personel autonomy in $\mathrm{VNU}$, the author would like to recommend the following: 
- Firstly, information about the government's and the Party's policies on education and training, science and technology should be disseminated among the staffs and particularly the scientiststo improve their awareness, to take advantage of the opportunity, to promote the role of VNU and to make full use of the preferences given by the Government, relevant agencies and Hanoi city. Meanwhile, democracy within the organization should be promoted, and the modeling and pioneering role of its staffs and students should be emphasized to build a strong and bonding community.

- Secondly, a comprehensive system ofmanagement documents to cover all relevant sectors, which forms the basis to increase decentralization to implementing units while ensuring VNU's examining and supervising power should be developed.

- Thirdly, enhancing flexible and connecting organizational structure and building sufficient and qualified working staffs at the member units are the key to success. VNU, therefore, should consider granting organization and personelautonomous power to its members gradually and appropriately and create high connectivity among VNU as well as within each unit. For the members to overcome difficulties once they are granted with autonomous power, VNU should review, evaluate and categorize the members to continue structured investment into the units that are still having difficulties with quality requirements such as those of human power, facilities, budget, etc.

- Fourthly, a flexible model of training and research should be developed, focusing on professional activities (training, researching, services, etc.) and increasing the application of information technology in management to minimize the number of administrative focal points and to support personnel management efficiently.

- Fifthly, all resources, first and foremost the human resource, should be fully exploited to promote the research and renovation potential and desire of VNU scientists and managerial staffs, the cooperation resource within and outside VNU in order to attract the cooperation of other experts, to diversify the financial resources and to attract investment into infrastructural facilities and to promote cooperation.

- Sixthly, a set of criteria to evaluate staff's professional capability at each working position should be developed. Basing on that, members can carry out staff evaluation bi-annually or annually. The result of such evaluation will be the basis for the unit leaders to assign tasks and responsibilities and to evaluate the level of task completion of each staff as well as the whole unit.

- Seventhly, current policies and regulations should be smartly applied so that decentralization government funding would be more effectively utilized to avoid widespread investment and losses at intermediate steps; and a mechanism of paying salary and extra earnings to the working staffs and the scientists basing on the evaluation of their capability and performance should be developed.

- Eighthly, policies to attract outstanding Vietnamese expatriates and overseas students to teach and research at VNU's key laboratories should be developed.

- Ninthly, connection to and cooperation with advanced universities in Asia and over the world should be further promoted for more exchange of scholars and further development of scientific resources [9].

\section{Acknowledgments}

This research is funded by Vietnam National University, Hanoi (VNU) under research project number QG.16.60. We acknowledge all the support from VNU Hanoi colleagues and from the Ministry of Training and Education. 


\section{References}

[1] John Fielden. 2008. Global Trends in University Governance. World Bank.

[2] Organization for Economic Cooperation and Development (OECD). 2003. 22 Governance reforms in higher educationvan Vught, 1994.

[3] Prime Minister (2006), Decree No. 43/2006/NDCP dated April $25^{\text {th }} 2006$ on the autonomy and self-responsibility power in duty implementation, organization, structure, personnel and finance at public administrative institutions.

[4] Prime Minister (2015), Decree No. 16/2015/NDCP dated February $14^{\text {th }} 2015$ governing the autonomy mechanism of public administrative institutions.
[5] Prime Minister (2013), Decree No. 186/2013/ND$\mathrm{CP}$ dated November $17^{\text {th }}$ on the National Universities.

[6] VNU (2016), Final Report of 2016.

[7] Vietnam National University, Hanoi (2014), Decision No. 3768/QD-DHQGHN dated October $22^{\text {th }} 2014$ on the issuance of the Regulations on the recruitment, employment, and management of staffs in Vietnam National University, Hanoi.

[8] Vietnam National University, Hanoi (2014), Decision No. 3568/QD-DHQGHN dated October $8^{\text {th }} 2014$ on the issuance of the Regulations on the organization and operation of VNU's member and subordinateUnits.

[9] Vietnam National University, Hanoi (2017), Report on the situation of and proposal for granting autonomous power to VNU's members.

\title{
Mô hình tự chủ về tổ chức bộ máy và quản lý nhân sự ở Đại học Quốc gia Hà Nội - Thực trạng và giải pháp
}

\author{
Nguyễn Kiều Oanh ${ }^{1}$, Phạm Thị Thanh Hải ${ }^{2}$, Trần Thị Hoài ${ }^{3}$ \\ ${ }^{1}$ Ban Tổ chức Cán bộ, Đại học Quốc gia Hà Nội, 144 Xuân Thuỷ, Cầu Giấy, Hà Nội, Việt Nam \\ ${ }^{2}$ Truoòng Đại học Giáo dục, Đại học Quốc gia Hà Nội, 144 Xuân Thuỷ, Cầu Giấy, Hà Nội, Việt Nam \\ ${ }^{3}$ Viện Đảm bảo Chẩt lượng Giáo dục, Đại học Quốc gia Hà Nội, \\ 144 Xuân Thuỷ, Cầu Giấy, Hà Nội, Việt Nam
}

Tóm tắt: Thể chế tự chủ cao hơn là chìa khóa cho các cải cách nhằm đa dạng hóa và huy động hiệu quả các nguồn lực trong giáo dục đại học tại Đại học Quốc gia Hà Nội (ĐHQGHN). Hiện nay, Chính phủ Việt Nam đã có chủ trương và ban hành một số hướng dẫn để giao thêm quyền tự chủ cho các cơ sở giáo dục đại học. ĐHQGHN đang tiến tới một hệ thống tự chủ để tối đa hóa việc sử dụng các nguồn lực nhằm đào tạo nguồn nhân lực chất lượng cao cho quốc gia. Quyền tự chủ về tổ chức bộ máy và quản lý nhân sự là điều kiện tiên quyết để một cơ sở giáo dục đại học thực hiện cơ chế tự chủ và chịu trách nhiệm giải trình với xã hội về các hoạt động đào tạo, nghiên cứu khoa học và chuyển giao công nghệ. Trong quá trình giao quyền tự chủ cho các cơ sở giáo dục đại học, cần nghiêm túc tính đến các yếu tố ảnh hưởng khách quan cũng như chủ quan để xây dựng các biện pháp thực thi hiệu quả, phù hợp với điều kiện kinh tế - xã hội và đặc thù riêng của từng cơ sở giáo dục đại học.

Tù khóa: Giáo dục đại học, tự chủ tại ĐHQGHN; mô hình tự chủ, quản lý nhân sự tại ĐHQGHN. 